\title{
From Mendel to Medical Genetics
}

\author{
Ulf Kristoffersson $^{1}$ and Milan Macek $^{\star, 2}$
}

European Journal of Human Genetics (2017) 25, S53-S59; doi:10.1038/ejhg.2017.157

\section{INTRODUCTION}

Only a few years after the rediscovery of Mendel's laws of inheritance in 1900, the first human genetic disorders and variants were described. ${ }^{1,2}$ Although these disorders were considered to be rare exceptions, the number of disorders to follow a Mendelian pattern of inheritance increased slowly. Victor McKusick, in his first volume of Mendelian Inheritance in Man published in 1966, listed 1486 entries, mainly phenotypes, whereas the current online catalogues contain over 8000 entries, with more than 5000 with a known molecular basis. ${ }^{3-5}$

The discovery of DNA as a carrier of the genetic code, its double helix structure and the rapidly developing possibility of the clinical use of chromosome- and DNA analyses made expertise in medical genetics (MG) valuable in health-care services and a subspecialty started to grow, mainly in gynaecology, neurology, paediatrics and laboratory medicine.

With the birth of the European Union (EU), a need for collaboration between established specialities emerged and the Union of European Medical Specialists (UEMS) ${ }^{6}$ was founded in the same year that the Treaty of Rome ${ }^{7}$ was signed. UEMS is an association of national medical professional organisations which focus on the harmonisation of training and education of medical doctors within and across all medical specialties. A number of specialities were soon mutually recognised in the member states as equivalent in training, leading to a national speciality licence being mutually recognised in all member states. At this time, MG was not recognised in any European country.

In this article, which includes the results of a recent survey, we describe the development of $\mathrm{MG}$ as a specialty in all European countries - not only within the EU itself - and the process undertaken in order to acquire its de iure recognition in the EU.

\section{THE PROCESS TO EUROPEAN UNION RECOGNITION}

The youthful status of our speciality is reflected in the fact that it has different names in different countries - MG, clinical genetics and human genetics being the most common, as they appear in the current version of European Directive 2005/36/EC on the recognition of professional qualifications ${ }^{8}$ (Professional Qualifications Directive; PQD). In this paper, we will refer to MG.

The process of becoming an EU-recognised speciality started with a discussion in the European Society of Human Genetics (ESHG) Public and Professional Policy committee shortly after it was founded in 1997, but it was too late to have MG included in the 1999 revision of the PQD.

At the ESHG board meeting in Munich 2004, Jean-Jacques Cassiman brought up the issue again, as he had met with the Secretary General of UEMS. After a discussion in the ESHG board, Ulf Kristoffersson was appointed to lead an ad hoc committee together with Dian Donnai, who were later replaced by Helen Kingston and Didier Lacombe. Their task was to draft common European guidelines for medical training with a specialisation in MG. After 2 years, we were finished and the document was endorsed by the ESHG membership.

Important support came with the adoption of the Organisation for Economic Co-operation and Development (OECD) 'Guidelines for quality assurance in molecular genetic testing' (2007), ${ }^{9}$ where many members of ESHG and the EuroGentest Network of Excellence EU project ${ }^{10}$ were involved in the drafting. Article E5 of the Guidelines stipulates that 'Relevant government or professional authorities should recognise MG as a discipline comprising both a clinical and a laboratory specialty,' thus underlining the multidisciplinary character of genetic services and the need for official recognition of the medical and clinical laboratory professional branches involved in the provision of genetic services (see later). Further significant backing for the recognition of MG emerged when, in May 2008, the first international legally binding instrument concerning genetic testing for health purposes was adopted by the Committee of Ministers of the Council of Europe. ${ }^{11}$

In parallel, we established contact with UEMS and initiated the procedures necessary for us to become a member organisation representing MG. Only recognised specialities could become 'sections', but if at least two recognised specialities so wished, a Multidisciplinary Joint Committee (MJC) could be formed. Thus, with help of the sections of Paediatrics and Obstetrics and Gynaecology, an MJC for 'Clinical Genetics' was formed according to the procedures and statutes of UEMS. Ulf Kristoffersson was elected the Chair and Helen Kingston the Secretary. Being an MJC, we received a voice in UEMS and afterwards the UEMS council also adopted our ESHG-approved training guidelines as UEMS guidelines: 'Description of Clinical Genetics as a medical specialty in the EU: Aims and objectives for specialist training' (April 2009; amended 2017). ${ }^{12}$

During the European Human Genetics Conference in Vienna on 25 May 2009, the vast majority of those attending the 5th Meeting of the Presidents of the National Human Genetics Societies (NHGS) $)^{13}$ signed a joint petition in support of the inclusion of MG in the PQD and endorsed the aforementioned UEMS consensus training curriculum. In addition, Jean-Jacques Cassiman contacted Frieda Brepoels, one of the Belgian members of the EU Parliament. She proposed a vote in favour of the recognition of MG in a Parliament Committee in March 2009. Unfortunately, there were not enough votes in favour for the motion to be carried.

Another important boost for the recognition of MG came from the successive French and Czech EU Council presidencies of the EU in July-December 2008 and January-June 2009, respectively. In November 2008, during the French term, John Burn and Arnold Munnich visited 
the French Minister of Health, Roselyne Bachelot, and asked for France to issue a formal request to the EC to start recognition proceedings. Indeed, the "French Request for inclusion of the specialty of MG under Annex V' into PQD was later officially filed, following additional support from French Orphanet representatives (Ségolène Aymé) in March 2009. Concurrently, Milan Macek was the chief government advisor to the Czech Presidency. He worked closely with EURORDISRare Diseases Europe, a non-profit alliance of over 700 European rare disease (RD) patient organisations (represented by Yann le Cam and his team) for the passage of the 'EU Council on Recommendation on an action in the field of RD (2009/C151/02). ${ }^{14}$ After intensive work at the Council and lobbying within the 6-month window of opportunity, this key EU document was adopted in June 2009.

The provisions of the Council Recommendation created a strong momentum for the recognition of MG by setting out the relevance of training in the specialty for the diagnosis of $\mathrm{RD}$, of which over $80 \%$ are genetic. Moreover, its Recital 15 provided us with justification for the cross-border mobility of MG (ie, 'expertise should travel rather than patients themselves'), it being the first line of diagnostic contact for the majority of these disorders. This clause was particularly relevant, since the PQD lists only those specialties where there is a justified need for cross-border provision of medical care and where there is a 'bottom up' consensus on a given postgraduate training curriculum by EU Member States for a particular medical specialty, that is, via the UEMS.

Following the French request to the EC, the ESHG worked with the NHGS representatives in providing the Recognition Committee (RC), an official EC body formed of member state representatives that has the power to authorise the EC to amend the PQD. At that time, EU presidents provided their national representatives at this committee with (a) endorsements of the UEMS consensus MG curriculum, including the harmonisation of respective national MG curricula with UEMS provisions and a minimal duration of postgraduate training of 4 years, (b) where applicable, legal dossiers stipulating national recognition of MG in their own countries and thus (c) 'evidencebased' support letters for the European recognition of MG. ${ }^{15}$ These activities were coordinated by Milan Macek, who at that time served as the President of the ESHG, and were spearheaded by the Czech RC representative (Lucia Slobodová). By mid-2010, the RC was provided with the official evidence that MG is recognised as a medical specialty at the national level in 20 of the $27 \mathrm{EU}$ member states, that is, as a primary specialty termed $8 \times$ 'clinical-', $10 \times$ 'medical-', $1 \times$ 'human-' and $1 \times$ genetics, while in Hungary MG was a subspecialty at that time. This overall number of national recognitions was greater than the qualified majority needed for a decisive vote by the RC (October 2010). Finally, on 3 March 2011, the EC adopted 'Regulation (EU) No 213/2011 amending Annexes II and V to Directive 2005/36/EC of the European Parliament and of the Council on the recognition of professional qualifications'. ${ }^{16}$ This administrative act means that MG is now officially recognised as a European specialty. Subsequently, EU recognition of MG facilitated national recognitions in Spain (2014), Belgium and Croatia (both 2017), the transition of MG to a primary specialty status in Hungary (2012) and the creation of a new professional society in Iceland (2012).

After the EU recognition we applied, with the help of the Swedish Medical Association, to form a Section for Clinical Genetics ${ }^{17}$ which was approved by the UEMS Council in 2013. Ulf Kristoffersson was elected the first president, and was followed by Bela Melegh in 2015. The three main tasks have been to update the training guidelines, to draft a syllabus for training and to develop a protocol for an European specialist exam planned to be offered for the first time in 2018. In 2016, the Section took the initiative of forming a 'MJC for Rare and

Undiagnosed Disorders (MJC-RUD)', in order to be able to form a bridge between the UEMS and the newly established European Reference Networks (ERN) for $\mathrm{RD}^{18}$ for collaboration on the harmonisation of MG training and education.

\section{THE DEVELOPMENT OF MEDICAL GENETICS IN EUROPE}

The 1997 survey 'Medical Genetics in Europe' provided evidence that 15 of the $24 \mathrm{EU}$ countries participating in this exercise recognised MG. ${ }^{19}$ In the spring of 2017, we performed an update of national legislative documents regulating $\mathrm{MG}$ in all member states of the Council of Europe, ${ }^{20} 47$ in all, adding Belarus as the only European country not being a member of this international organisation, and Israel, which is an 'Observer to the Parliamentary Assembly'. Five minor

Table 1 Current status of the medical genetics specialty in Europe: results of a 2017 survey

No of countries in the Council of

Europe 47

Belarus added

Countries not included

No or incomplete data

Countries included

No established specialty

No specialty but subspecialty

Currently primary specialty

Subspecialty before 1997

Primary specialty before 1997

Table 2 Agregated data on the year of recognition of medical genetics specialisation and/or subspecialisation

\begin{tabular}{lccc}
\hline $\begin{array}{l}\text { Year for specialty } \\
\text { recognised }\end{array}$ & $\begin{array}{c}\text { Subspecialty } \\
\text { recognised }\end{array}$ & Still subspecialty & $\begin{array}{c}\text { Before } \\
\text { specialty }\end{array}$ \\
\hline XXXX-1975 & 2 & 4 & 1 \\
$1976-1980$ & 0 & 4 & 2 \\
$1981-1985$ & 2 & 0 & 0 \\
$1986-1990$ & 1 & 2 & 3 \\
$1991-1995$ & 3 & 6 & 0 \\
$1996-2000$ & 3 & 1 & 0 \\
$2001-2005$ & 5 & 0 & 0 \\
$2006-2010$ & 8 & 0 & 0 \\
$2011-2015$ & 6 & 0 & 0 \\
$2016-2017$ & 2 & 0 & 0 \\
Sum & 30 & 17 & 6 \\
No data & 2 & & \\
\hline
\end{tabular}

Table 3 Length of postgraduate training in the medical genetics specialty

Years of training for primary specialisation

\begin{tabular}{lr}
\hline years & 1 \\
4 years & 16 \\
5 years & 8 \\
6 years & 2 \\
Missing data & 5 \\
Sum & 32
\end{tabular}


From Mendel to Medical Genetics

U Kristoffersson and M Mace k

S55

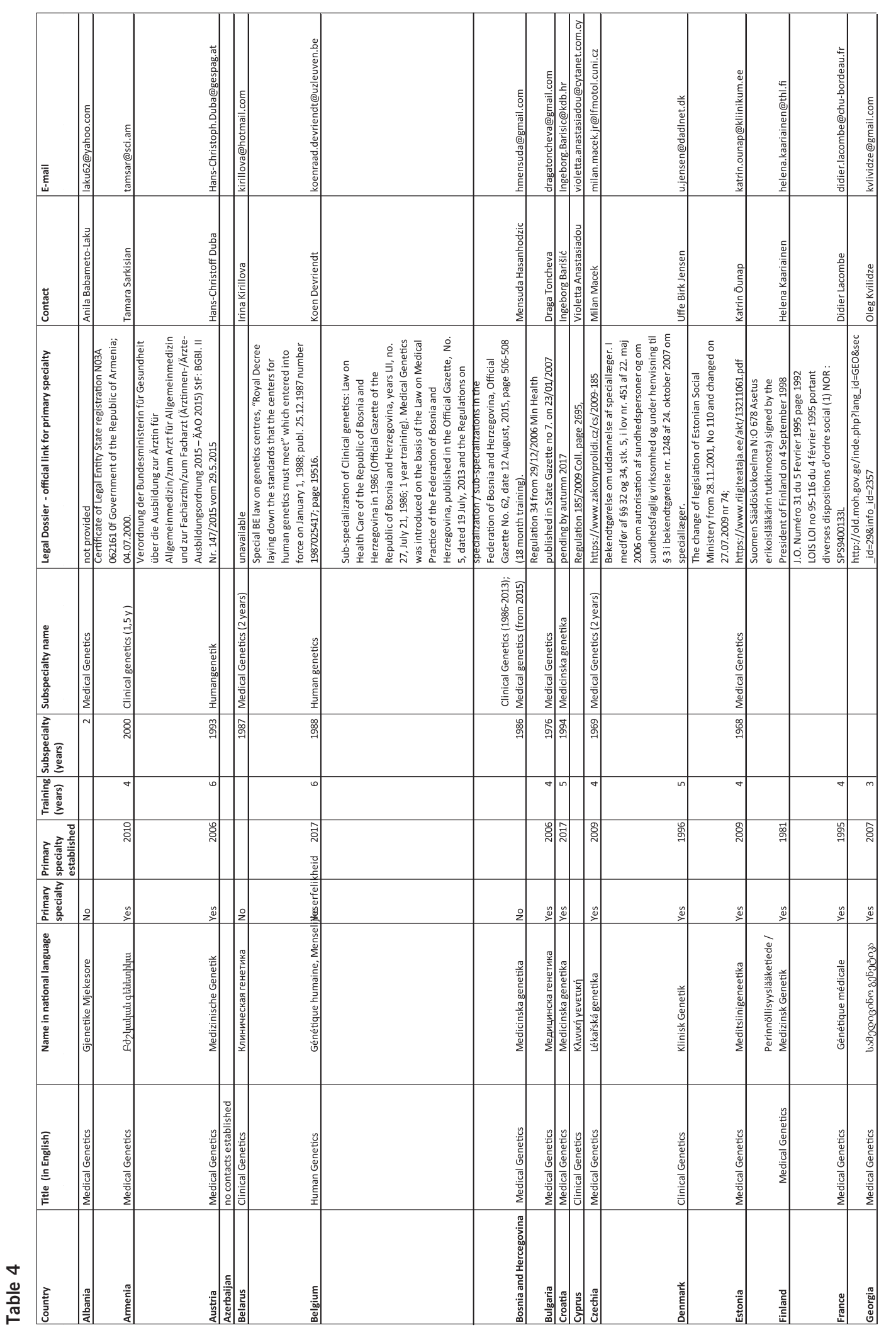

European Journal of Human Genetics 


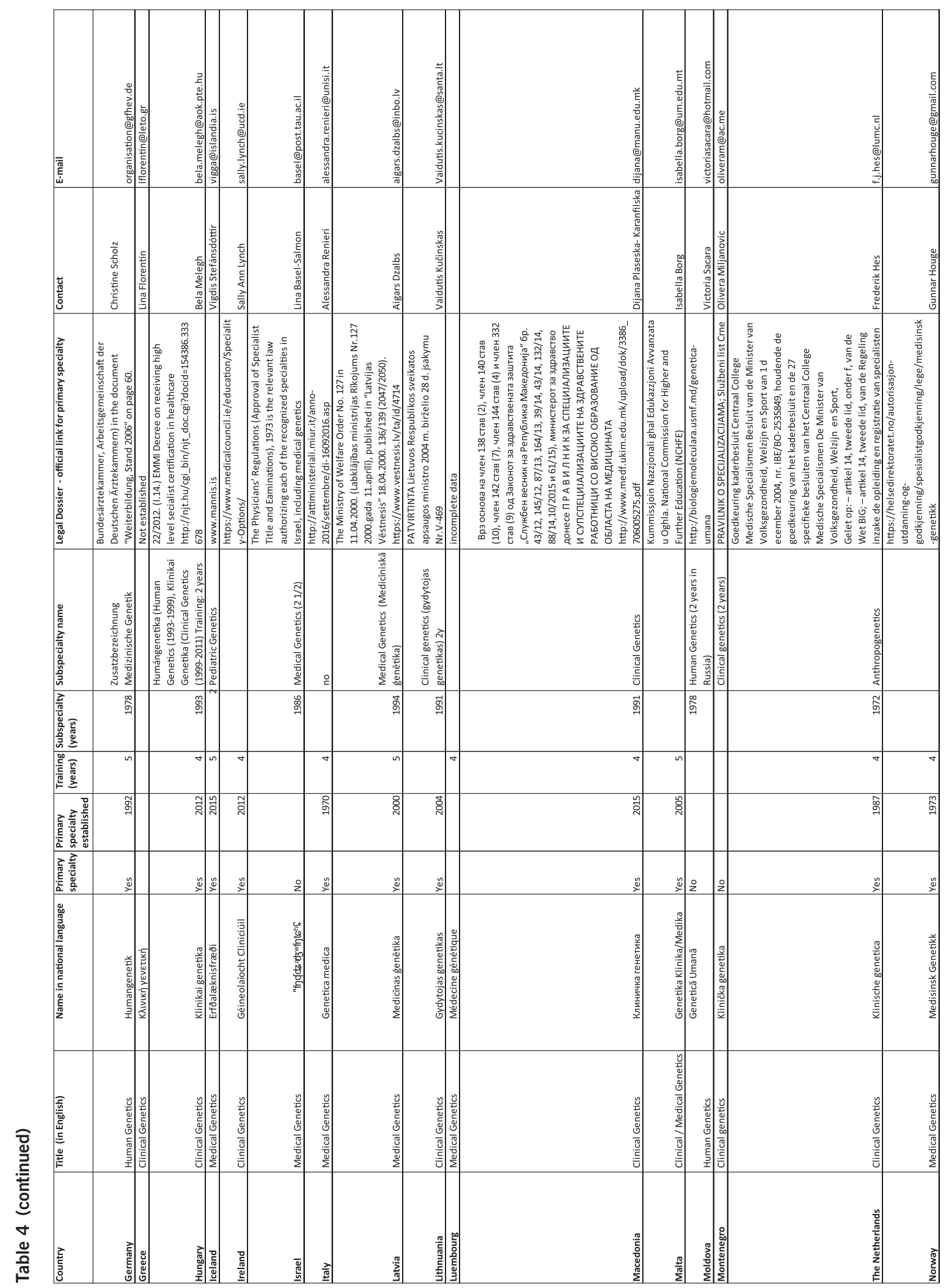




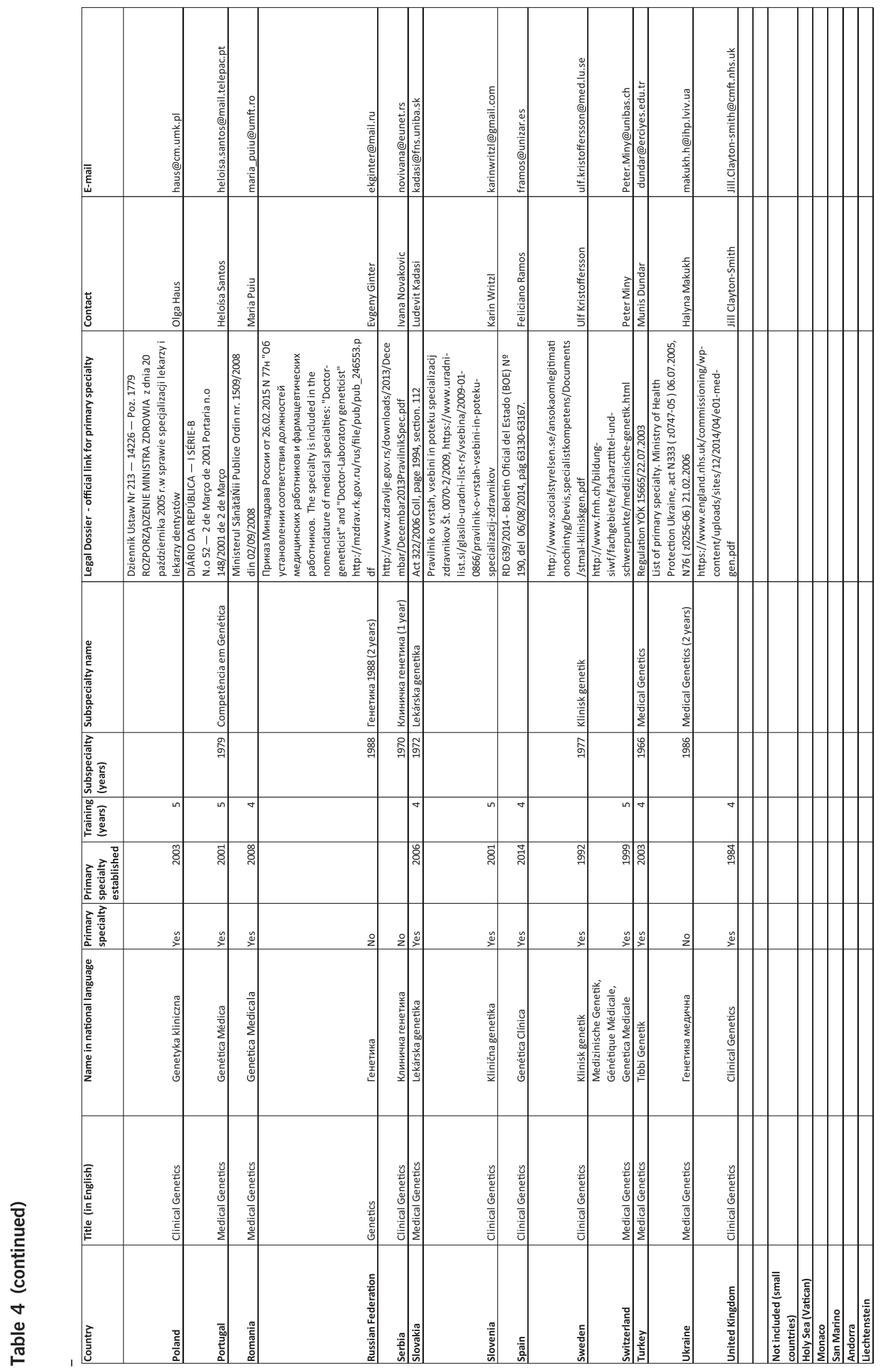


member states were not included in this survey (Andorra, Lichtenstein, Monaco, San Marino and the Vatican) as they usually utilise the provisions and/or genetic services of their neighbouring countries. From one country, Azerbaijan, no information was available (Table 1) and for Luxembourg information was drawn from the data listed in the PQD. In Table 2 aggregated data on the year of recognition of specialisation and/or subspecialisation is presented, and in Table 3 the length of training is summarised (data drawn from the Table 4).

\section{DISCUSSION}

At present all but two European countries, Greece and Cyprus, have recognised the MG speciality; Belgium and Croatia as late as this year. Seventeen countries recognised MG as a subspecialty before 2000, and nine of them later changed the status to a stand-alone, that is, primary, speciality. This recognition went slowly until the turn of the millennium, when the scientific progress in human molecular genetics made the discipline an important partner in the development of health care and further evolved with the concept of personalised (stratified or precision) medicine. Full recognition was adopted in 21 countries, that is, about half of the Council of Europe member states, after 2000 (see above).

Training requirements for specialisation varies between the countries ranges from 3 to 6 years, the most common duration being 4 years which is also the minimum length stipulated by PQD. The content of training varies between countries, especially regarding the amount of laboratory competence needed and requirement of clinical electives in other related medical specialties (eg, gynaecology, neurology and/or paediatrics). In spite of the different languages and the varying tasks of a specialist in MG in different European countries, we have now the possibility of working in many different settings and environments, an opportunity that we hope many young doctors will take advantage of.

MG also aims to collaborate closely with the two other professional branches involved in genetic services, clinical laboratory geneticists and genetic nurses and counsellors, under the auspices of the European Board of Medical Genetics (EBMG). ${ }^{21}$ This independent board was established in 2012 to serve the needs of patients through establishing standards of practice in all professional branches providing genetic services, and to ultimately issue professional certifications.

Finally, recognition of MG will also aid implementation of Articles 54 and 55 of Directive 2011/24/EU of the European Parliament and of the Council on the application of patients' rights in cross-border healthcare, ${ }^{22}$ which provide special provisions for $\mathrm{RD}$ and was seminal for the development of ERNs, where MG is embedded as a core specialty in the majority of their cross-border, interdisciplinary research and diagnostic activities.

\section{CONFLICT OF INTEREST}

The authors declare no conflict of interest.

\section{ACKNOWLEDGEMENTS}

Due to space limitations, we apologise that we could not list all other individuals who were instrumental for the recognition of $\mathrm{MG}$, to whom we are nonetheless very grateful for their work. We also would like to acknowledge the contribution of colleagues who provided national data for the 2017 survey (In country order, without titles): Anila Babameto-Laku, Tamara Sarkisian, HansChristoff Duba, Irina Kirillova, Koen Devriendt, Mensuda Hasanhodzic, Draga Toncheva, Ingeborg Barišić, Violetta Anastasiadou, Uffe Birk Jensen, Katrin Õunap, Helena Kääriäinen, Didier Lacombe, Oleg Kvilidze, Christine Scholz, Lina Florentin, Bela Melegh, Vigdis Stefánsdóttir, Sally Ann Lynch, Lina BaselSalmon, Alessandra Renieri, Aigars Dzalbs, Vaidutis Kučinskas, Dijana Plašeska-Karanfilska, Isabella Borg, Victoria Sacara, Olivera Miljanovič, Frederik Hes, Gunnar Houge, Olga Haus, Heloísa Santos, Maria Puiu, Evgeny Ginter, Ivana Novakovič, Ludevít Kádaši, Karin Writzl, Feliciano Ramos,
Peter Miny, Munis Dundar, Halyna Makukh and Jill Clayton-Smith (see Supplementary Table). This work was supported by CZ.2.16/3.1.00/ 24022OPPK; CZ.02.1.01/0.0/0.0/16_013/0001634, 00064203 (6003) and LM2015091 to MM.

1 Garrod AE: The incidence of alkaptonurea: a study in chemical individuality. Lancet 1902; 2: 1616-1620.

2 Landsteiner K: Ueber agglutinationserscheinungen normalen menschlichen Blutes. Wiener Klinische Wochenschrift 1901; 46: 1132-1134.

3 McKusick VAMendelian inheritance in man, a catalogue of autosomal dominantAutosomal Recessive, and X-linked Phenotypes1st edn.Baltimore, MD: Johns Hopkins University Press, (1966) .

4 Online Mendelian Inheritance in Man. An Online Catalog of Human Genes and Genetic Disorders (OMIM), 2017 https://www.omim.org/statistics/entry (accessed 8 September 2017).

5 Orphanet, 2017 https://www.orpha.net (accessed 8 September 2017).

6 European Union of Medical Specialists, 2017 https://www.uems.eu (accessed 8 September 2017).

7 Treaty of Rome, 2017 http://eur-lex.europa.eu/legal-content/CS/TXT/?uri=LEGISSUM: xy0023 (accessed 8 September 2017.

8 DIRECTIVE 2005/36/EC of the European Parliament and of the Council of 7 September 2005 on the recognition of professional qualifications Professional Qualifications Directive http://eur-lex.europa.eu/legal-content/EN/TXT/PDF/?uri = CELEX:32005L0036\&from = CS (accessed 8 September 2017).

9 OECD guidelines for quality assurance in molecular genetic testing, $2017 \mathrm{http}: / / \mathrm{www}$. oecd.org/sti/biotech/38839788.pdf (accessed 8 September 2017).

10 Cassiman JJ: Research network: EuroGentest-a European Network of Excellence aimed at harmonizing genetic testing services. Eur J Hum Genet 2005; 13: 1103-1105.

11 Lwoff L2009 Council of Europe adopts protocol on genetic testing for health purposes. Eur J Hum Genet 2009; 17: 1374-1377.

12 EU. Description of Clinical Genetics as a medical specialty in EU. Aims and objectives for specialist training. (2009; amended 2017) https://www.uems.eu/ data/assets/ pdf_file/0007/47518/ETR_Clinical-Genetics_approved.pdf (accessed 8 September 2017).

13 National Human Genetics Societies (NHGS; European Society of Human Genetics), 2017 https://www.eshg.org/76.0.html (accessed 8 September 2017).

14 Council on Recommendation on an Action in the Field of Rare Diseases (2009/C151/02) http://eur-lex.europa.eu/LexUriServ/LexUriServ.do?uri=OJ:C:2009:151: 0007:0010:EN:PDF (accessed 8 September 2017).

15 European Society of Human Genetics. Genetics as Medical Specialty in Europe, 2017 https://www.eshg.org/index.php?id = 111 (accessed 8 September 2017).

16 Commission Regulation (EU) No 213/2011 of 3 March 2011 amending Annexes II and V to Directive 2005/36/EC of the European Parliament and of the Council on the recognition of professional qualifications http://eur-lex.europa.eu/LexUriServ/LexUriServ.do?uri = OJ:L:2011:059:0004:0007:EN:PDF (accessed 8 September 2017).

17 Section on Clinical Genetics - European Union of Medical Specialists. 2017 http:// clinicalgenetics-uems.pte.hu/ (accessed 8 September 2017).

18 Héon-Klin V: European reference networks for rare diseases: what is the conceptual framework? Orphanet J Rare Dis 2017; 12: 137.

19 Harris R, Reid M1997 Medical Genetic services in 31 countries: an overview. Eur J Hum Genet 1997; 5 (Suppl 2): 3-21.

20 Council of Europe, 2017 https://www.coe.int/en/web/portal/home (accessed 8 September 2017).

21 European Board of Medical Genetics (EBMG). 2017 https://www.eshg.org/413.0.html (accessed 8 September 2017).

22 Directive 2011/24/EU of the European Parliament and of the Council of 9 March 2011 on the application of patients' rights in cross-border healthcare http://eur-lex.europa.eu/ legal-content/EN/TXT/PDF/?uri=CELEX:32011L0024\&from =EN (accessed 8 September 2017).

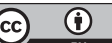

Open Access This article is licensed under a Creative Commons Attribution 4.0 International License, which permits use, sharing, adaptation, distribution and reproduction in any medium or format, as long as you give appropriate credit to the original author(s) and the source, provide a link to the Creative Commons license, and indicate if changes were made. The images or other third party material in this article are included in the article's Creative Commons license, unless indicated otherwise in a credit line to the material. If material is not included in the article's Creative Commons license and your intended use is not permitted by statutory regulation or exceeds the permitted use, you will need to obtain permission directly from the copyright holder. To view a copy of this license, visit http:// creativecommons.org/licenses/by/4.0/

(C) The Author(s) 2017 


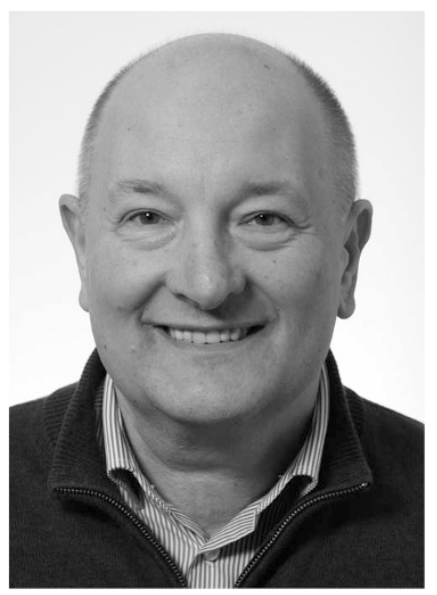

Professor Milan Macek Jr. MD, DSc is the chairman of the Department of Medical- and Molecular genetics at $2^{\text {nd }}$ Faculty of Medicine of Charles University Prague and University Hospital Motol (www.fnmotol.cz/ublg) and head of the National Coordination Centre for Rare Diseases (www. nkcvo.cz) within this department. He is also co-chairman of the National Cystic Fibrosis Centre. He studied medicine and has his paediatric residency training at Charles University Prague, did postdoctoral stays at Institute of Human Genetics, Humboldt University, Berlin and McKusick Nathans Center for Genomic Medicine at Johns Hopkins University, Baltimore. His main research interests comprise molecular genetics of rare diseases, development of novel therapies in cystic fibrosis, including involvement in public health initiatives related to rare disease-related diagnostics and care. In this regard, he has been member of the EUCERD- (European Union Committee of Experts on Rare Diseases) and its successive CEGRD (Commission Expert Group on Rare Diseases) committees. Prof. Macek's department serves as a 'clearing centre' for dissemination of knowledge in rare disease-related genetics/genomics gathered within various International collaborative European research projects, such as CF Thematic Network, EuroGentest I-II, EuroCareCF, RD-Connect, Eurenomics, Techgene, 3Gb-test, Orphanet, RDAction or Norway Grants schemes to Central / Eastern European and the Middle Eastern diagnostic-/ research groups. Prof. Macek is also the Czech National coordinator of Orphanet and member of the Diagnostic Committee of the International Rare Disease Consortium. He was involved in the drafting of the Czech National Strategy for Rare Diseases, the Czech National Plans for Rare Diseases and the drafting of Czech genetics legislature. During the Czech EU Council Presidency he served as the chief government advisor for the adoption of the 'EU Council Reccommendation on an action in the field of rare diseases'. Currently, he is involved in the adoption of the 'Additional protocol on genetic testing for health care purposes' to the Oviedo 'Convention on Human Rights and Biomedicine' by the Czech Republic, which will enable its entry into force for the Council of Europe countries. He is past President of the European Society of Human Genetics, and past board member of the European Cystic Fibrosis Society and the European Society for Human Reproduction and Embryology. He hosted the 1995 HUGO Mutation Detection Course in Brno, the 2005 European Society of Human Genetics conference and the 2008 European Cystic Fibrosis Conference, both held in Prague. Within the ESHG Board he serves as liaison for European National Human Genetics Societies and for intersociety (ESHG and ESHRE) joint position statements on reproductive genetics. Under his term as President of the ESHG he was involved in the recognition of clinical-/medical genetics as a European specialty via amendment of the European 'Professional Qualifications Directive'.

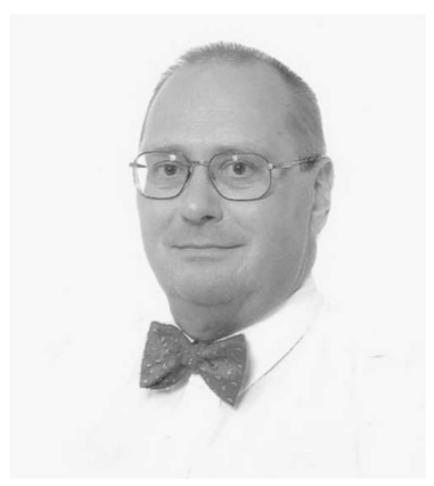

Ulf Kristoffersson worked as Associate Professor and Senior Consultant at Lund University and Region Skåne Health Care Service, and as Head of Department from 2000 to 2012. At present, he is the head of the South Swedish Rare Diseases Centre. His ESHG-related activities include the following: Board Member, 1997 - 2001; PPPC founding member, 1997 - 2007; Chair, Ad hoc Committee for European recognition of Medical Genetics as a medical specialty and UEMS MJC for Medical Genetics, 2004 - 2012; Chair UEMS section for Medical Genetics, 2013 - 2015 ; and past president, 2016 - 2020. He was the Vice President of EBMG and chair, MD section, from 2014 to 2015, has been a member from 2015 until the present. 